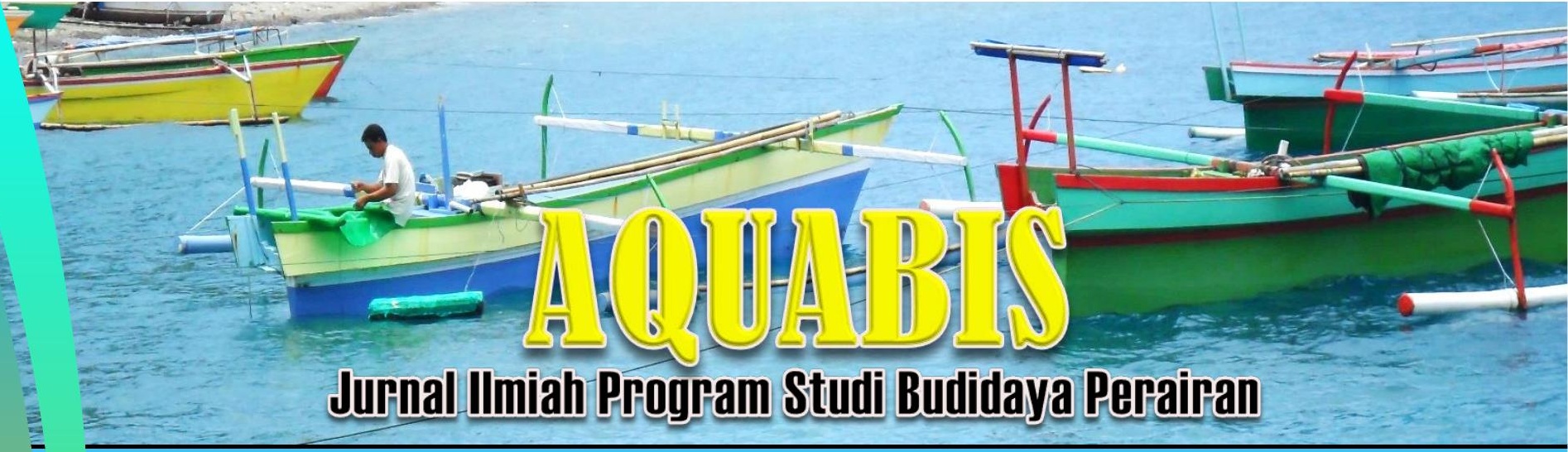

Volume 6 Nomor 1 Juni 2017

ISSN: 2301-5705

FAKTOR TEKNIS PENANGKAPAN TERHADAP DAMPAK TEKANAN POPULASI IKAN CAKALANG (Katsuwonus pelamis) DI PERAIRAN LAUT FLORES

Asruddin 1

KONSENTRASI LOGAM BERAT TIMBAL (PB) PADA SEDIMEN DAN IKAN NILA (Oreochromis niloticus) DI SUNGAI BIYONGA KABUPATEN GORONTALO

Sri Yuningsih Noor. 7

ANALISIS KELAYAKAN PANGKALAN PENDARATAN IKAN (PPI) TENDA KOTA GORONTALO DITINJAU DARI FASILITAS POKOK, FUNGSIONAL, DAN PENUNJANG

Muh. Yasin Umsini Putra Oli’ii dan Noval Saputra Yintili..... 13

BUDIDAYA IKAN AIR TAWAR SISTEM POLIKULTUR MENGGUNAKAN JARING TANCAP DI DANAU LIMBOTO

Yulianty Adipu

PEMANFAATAN KEONG MAS (Pomacea caniculata) SEBAGAI SUMBER BAHAN BAKU PAKAN IKAN

Titin Liana Febriyanti.

FREKUENSI PENCUCIAN YANG BERBEDA TERHADAP KEKUATAN GEL DAN PROTEIN LARUT GARAM SURIMI IKAN MANGGABAI (Glossogobius giuris)

Rahyuni Sy. Domili.

TELAAH KOMPOSISI IKAN KARANG DAN KOMUNITAS KARANG KELURAHAN BUNTA II DAN DESA MINAHAKI KABUPATEN BANGGAI Mohamad Sayuti Djau 


\title{
FAKTOR TEKNIS PENANGKAPAN TERHADAP DAMPAK TEKANAN POPULASI IKAN CAKALANG (Katsuwonus pelamis) DI PERAIRAN LAUT FLORES
}

\author{
Asruddin \\ Program Studi Budidaya Perairan Fakultas Ilmu- Ilmu Pertanian \\ Universitas Muhammadiyah Gorontalo \\ Email : rudisiago@umgo.ac.id
}

\begin{abstract}
This research aims to know the capabilities of the fishing gear and skipjack tuna CPUE levels in the Flores Sea. The research method used direct observation in the field by following the arrest operations and conduct interviews to the fisherman of purse seine semi-active, purse seine active and drift gill net. The analysis used in this research is measuring the fishing gear ability and levels of CPUE skipjack tuna in the Flores Sea. Based on the percentage of capture ability of skipjack tuna obtained that the highest capture capability is on purse sein semi-active fishing gear where to catch the skipjack tuna by $0.36 \mathrm{~kg}$ in one minute. Based on the analysis of the CPUE of skipjack tuna in the Flores sea from 2007-2012, skipjack tuna production has an increase the calculation of MSY (Maximum Sustainable Yield) of 2464.8 tons. Meanwhile, in 2012 skipjack tuna production have overfishing from the MSY. The population of skipjack tuna in the Flores sea is likely to have pressured by technical factors of fishing.
\end{abstract}

Keywords : Impact of technology, skipjack population,, Flores Sea

\begin{abstract}
Abstrak
Penelitian ini bertujuan untuk mengetahui kemampuan alat tangkap ikan cakalang dan tingkat CPUE ikan cakalang di Perairan Laut Flores. Metode penelitian yang digunakan adalah metode pengamatan langsung di lapangan dengan mengikuti kegiatan operasi penangkapan dan melakukan wawancara kepada nelayan pukat cincin semi aktif, pukat cincin aktif dan jaring insang hanyut. Hasil analisis yang digunakan dalam penelitian yaitu pengukuran kemampuan alat tangkap dan Tingkat CPUE ikan cakalang di Perairan Laut Flores. Berdasarkan persentase kemampuan tangkap terhadap ikan cakalang diperoleh bahwa Kemampuan tangkap yang tertinggi terdapat pada alat tangkap pukat cincin semi aktif dimana dapat menangkap ikan cakalang sebesar 0,36 $\mathrm{kg}$ dalam satu menitnya. Berdasarkan analisis tingkat CPUE ikan cakalang di Laut Flores dari tahun 2007-2012, produksi ikan cakalang telah mengalami peningkatan hasil perhitungan MSY (Maksimum Sustainable Yield) yaitu sebesar 2464,8 ton sementara itu pada tahun 2012 tingkat produksi ikan cakalang telah melebihi nilai MSYnya. Populasi ikan cakalang di perairan laut flores cenderung telah mengalami tekanan oleh faktor teknis penangkapan ikan.
\end{abstract}

Kata kunci: Kemampuan tangkap, tingkat CPUE, Populasi Ikan Cakalang

\section{PENDAHULUAN}

Perairan Laut Flores merupakan Wilayah Pengelolaan Perikanan Republik Indonesia (WPP-RI 713) yang kawasan perairannya ini kaya akan sumberdaya ikan pelagis besar dan salah satu diantaranya adalah ikan cakalang (Katsuwonus pelamis). Ikan cakalang merupakan komoditas perikanan penting yang bernilai ekonomis tinggi dan telah dimanfaatkan sejak lama dengan menggunakan berbagai alat tangkap dan tingkat teknologi yang bervariasi seperti huhate (pole and line), pancing tangan (hand line), pancing tonda (trolling line), pukat cincin (purse seine) dan kadang jaring insang permukaan (surface gill net) yang menggunakan alat bantu rumpon atau memburu gerombolan ikan (Yahya, et al, 2001).

Populasi ikan cakalang merupakan ikan yang bergorombol dan pada umur tertentu ikan tersebut akan melakukan bermigrasi sehingga pengelolaan keberlanjutan ikan cakalang perlu dilakukan di setiap wilayah yang dilalui oleh 
alur miggrasi ikan cakalang tersebut. Beberapa daerah yang dilalui alur migrasi ikan cakalang adalah perairan teluk Bone, Perairan Selayar, Selat makassar dan tentunya perairan laut flores. Wilayah-wilayah tersebut telah banyak peneliti melakukan riset di wilayah tersebut antara lain Mallawa et al (2016) diperiran laut flores memiliki ukuran hasil tangkap yang berbeda antara satu tempat dengan tempat lainnya dan bentuk ukuran ikan cakalan yang tertangkap di perairan tersebut hampir-hampir sama dengan tempat lainnya.

Penelitian lainnya yang melakukan riset di laut flores dan perairan sekitarnya seperti perairan selayar dan perairan bulukumba antara lain; Mustafa (2007), meneliti tentang keramahan lingkungan beberapa jenis alat tangkap ikan kembung lelaki (Rastelliger kanagurata) di perairan Kabupaten Bulukkumba. Sedangkan penelitian ikan cakalang di perairan Laut Flores sendiri antara lain; Rukka (2006), meneliti teknologi penangkapan pilihan untuk ikan cakalang di perairan Selayar Propinsi Sulawesi Selatan. Zainuddin (2009), meneliti tentang estimasi potensi dan pemetaan daerah potensial penangkapan ikan pelagis di perairan Selayar dengan menggunakan citra satelit aqua/modis. Zainuddin et al (2013), meneliti karakterisasi zona potensial perikanan cakalang selama monsoon tenggara di Perairan Bone dan Laut Flores menggunakan penginderaan jauh data kelautan.

Berdasarkan uraian tersebut akan lebih mudah melakukan kebijakan dalam hal pengelolaan status ikan cakalang dengan banyaknya penelitian diperairan laut flores dan perairan disekitarnya sehingga untuk melengkapi penelitian tersebut penulis melakukan penelitian mengenai faktor teknis penangkapan terhadap dampak tekanan populasi ikan cakalang (Katsuwonus pelamis) di perairan laut flores seperti tingkat CPUE dan kemampuan suatu alat tangkap terhadap tangkapn ikan cakalang.

\section{METODE PENELITIAN Jenis dan Sumber Data}

Jenis data yang digunakan dan yang akan diolah sebagai bentuk data primer adalah rata-rata ikan cakalang $(\mathrm{cm})$, tempat atau wilayah penangkapan, hasil tangkapn yang diperoleh. Data tersebut di capai dengan menggunkan survey serta melakukan beberapa pertanyaan kepada nelayan untuk memperoleh data. Data sekuder yang digunakan berasal dari data Dinas Perikanan Sulawesi Selatan.

\section{Analisis Data}

Analisis tekanan teknologi terhadap populasi ikan dapat dilihat dari tingkat CPUE alat tangkap, Kemampuan alat tangkap dan persentase ukuran layak tangkap. Untuk menghitung Catch Per Unit Effort (CPUE) ikan cakalang, digunakan rumus:

$$
C P U E=P / E
$$

CPUE merupakan produksi per unit upaya (ton/trip), $\mathrm{P}$ adalah produksi/jumlah hasil tangkapan (ton), E merupakan upaya penangkapan (trip). Data yang dianalisis secara deskriptif pada data hasil produksi selam lima tahun terakhir. Kemudian menghitung kemampuan tangkap dengan rumus:

$$
F=q / f
$$

Dari rumus diatas menunjukkan bahwa F merupakan kemampuan tangkap, q adalah catch tangkapan, dan $f$ adalah upaya penangkapan (lama operasi penangkapan. Data yang dianalisis adalah data hasil tangkapan ikan cakalang pada alat tangkap pukat cincin aktif, pukat cincin semi aktif dan jaring insang hanyut untuk memperoleh kemampuan tangkapnya terhadap ikan cakalang.

\section{HASIL DAN PEMBAHASAN}

Dampak tekanan teknologi alat tangkap terhadap populasi ikan cakalang dianalisis melalui hasil produksi, upaya penangkapan baik berupa jumlah dan kemampuan tangkap dan persentase ukuran hasil tangkapan yang layak tangkap. Ada beberapa indikator yang di analisis untuk mengetahui dampak tekanan teknologi alat tangkap ikan terhadap suatu populasi ikan cakalang sebagai berikut:

\section{CPUE Ikan Cakalang Alat Tangkap Pukat Cincin dan Jaring Insang Hanyut}

Pada data primer dari hasil produksi purse seine non rumpon, purse seine plus rumpon dan gill net oleh nelayan sampel di Kabupaten Bulukumba selama 23-26 sampel penangkapan dimana ketiga alat tangkap tersebut memiliki jumlah trip yang berbedabeda. Pada alat tangkap purse seine plus 
rumpon memiliki jumlah trip 26 trip dengan hasil tangkapan sebesar $12460 \mathrm{~kg}$. Pada alat tangkap purse seine non rumpon memiliki jumlah 41 trip dengan hasil tangkapan $9415 \mathrm{~kg}$ sedangkan pada alat tangkap gill net memiliki jumlah trip 16 dengan hasil porolehan tangkapan sebesar 62,7 kg (Tabel 1).

Tabel 1. Persentase CPUE ikan cakalang pada alat tangkap pukat cincin semi aktif, pukat cincin aktif dan jaring insang hanyut

\begin{tabular}{lcccc}
\hline \multicolumn{1}{c}{$\begin{array}{c}\text { Jenis alat } \\
\text { tangkap }\end{array}$} & $\begin{array}{c}\text { Jumlah } \\
\text { trip }\end{array}$ & $\begin{array}{c}\text { Hasil } \\
\text { tangkapan } \\
\text { (kg) }\end{array}$ & Cpue(kg/trip) & $\%$ \\
\hline $\begin{array}{l}\text { Pukat cincin } \\
\text { aktif }\end{array}$ & 41 & 9415 & 229.6341463 & 32.28 \\
$\begin{array}{l}\text { Pukat cincin } \\
\text { semi aktif }\end{array}$ & 26 & 12460 & 479.2307692 & 67.36 \\
$\begin{array}{l}\text { Jaring } \\
\text { insang } \\
\text { hanyut }\end{array}$ & 25 & 62.7 & 2.508 & 0.35 \\
\hline Jumlah & & & & \\
\hline
\end{tabular}

CPUE ikan cakalang pada alat tangkap pukat cincin semi aktif memiliki nilai $67.36 \%$. Untuk CPUE pada alat tangkap pukat cincin aktif memiliki nilai $32.28 \%$ sedangkan pada CPUE ikan cakalang pada alat tangkap gill net hanya mencapai $0.35 \%$. Dari hasil analisis bahwa CPUE ikan cakalang pada alat tangkap pukat cincin semi aktif lebih tinggi dibandingkan alat tangkap yang lainnya. Demikian pula pada alat tangkap pukat cincin aktif juga lebih tinggi dibandingkan dengan alat tangkap jaring insang hanyut.

Untuk mengetahui tekanan populasi ikan cakalang di perairan Laut Flores oleh teknologi alat tangkap haruslah memiliki data yang cukup, sehingga perkembangan CPUE ikan cakalang dapat dianalisis seberapa upaya yang dilakukan sehingga populasi ikan cakalang tidak mengalami tekanan akibat jumlah upaya atau trip penangkapan yang menghasilkan produksi tidak melebihi batas optimum. Pada alat tangkap pukat cincin dalam penangkapan ikan cakalang di perairan Laut Flores selama 5 tahun terakhir dari tahun 2007-2012 telah mengalami peningkatan mulai dari tahun 2007 sampai tahun 2009 yang mencapai 1950,3 ton dan pada tahun 2010 mengalami penurunan 110,1 ton yang hanya mencapai 1950,3 ton. Pada tahun 2011 masih mengalami penurunan sebesar 468,5 ton yang hanya mencapai 1481,7 ton dan pada tahun 2012 mengalami peningkatan sebesar 2568,3 ton (Gambar 2).

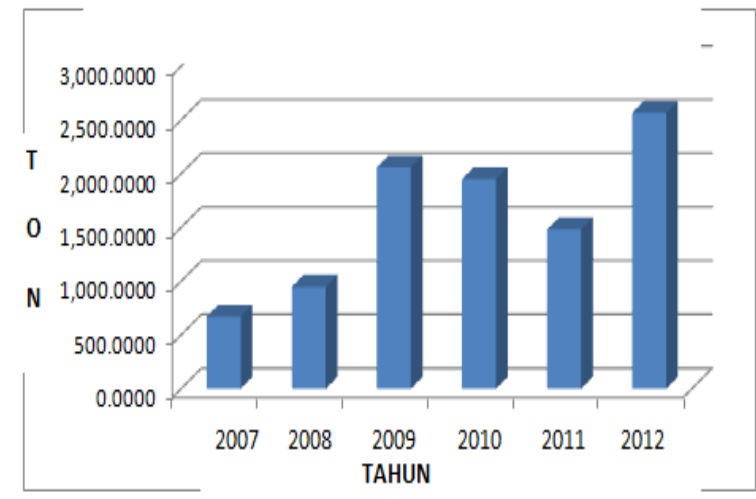

Gambar 2. Perkembangan hasil produksi pada alat tangkap pukat cincin dari tahun 2007-2012 di Perairan Laut Flores ditataran wilayah WPP-RI 713 (Sumber: Dinas Perikanan dan Kelautan Provinsi Sulawesi Selatan)

Hasil tangkapan per unit upaya atau Catch Per Unit Effort (CPUE) merupakan angka yang menggambarkan perbandingan antara hasil tangkapan per unit upaya atau usaha. Dimana, nilai ini dapat digunakan untuk melihat kemampuan sumberdaya apabila dieksplotasi terus menerus. Hasil tangkapan per unit upaya ikan cakalang pada penggunaan alat tangkap pukat cincin di perairan Laut Flores dari data sekunder yang diperoleh dari Dinas Perikanan Propinsi Sulawesi Selatan 5 tahun terakhir (2007-2012) dimana CPUE mengalami peningkatan dan juga semakin bertambahnya upaya penangkapan.

Dari hasil analisis data bahwa potensi lestari atau MSY (Maksimum Sustainable Yield) sebesar 2464,8 ton dimana pada tahun 2012 telah melebihi MSYnya sehingga pada alat tangkap pukat cincin di perairan Laut Flores telah cenderung member tekanan terhadap populasi ikan cakalang dan juga tingkat optimum hasil tangkapan sudah melebihi bagian dari potensi lestari (lebih $100 \%$ ) dan hal ini penambahan upaya tidak dapat meningkatkan hasil. Populasi ikan yang mengalami tekanan eksploitasi dapat ditandai dari ukuran ikan cakalang yang semekin kecil ukurannya. Dikatan oleh Mallawa et.al (2016) keadaan populasi ikan cakalang di perairan Laut Flores telah matang gonad pada ukuran di atas lima puluh satu $\mathrm{cm}$ dan dapat mijah pada ukuran di atas ukuran $55 \mathrm{~cm}$ untuk ikan betina dan di atas ukuran $60 \mathrm{~cm}$ pada jantan. 
Ikan cakalang yang termasuk kategori ikan layak tangkap di Perairan Laut Flores adalah sama dengan atau di atas ukuran $60 \mathrm{~cm}$. Untuk alat tangkap jaring insang hanyut dalam penangkapan ikan cakalang di perairan Laut Flores selama 5 tahun terakhir dari tahun 2007 -
2012 telah mengalami peningkatan mulai dari tahun 2007 sampai tahun 2012. Pada tahun 2007 sebesar 191, 6 ton dan pada tahun 2012 mengalami peningkatan yang signifikan sebesar 1054,2 ton (Gambar 3).

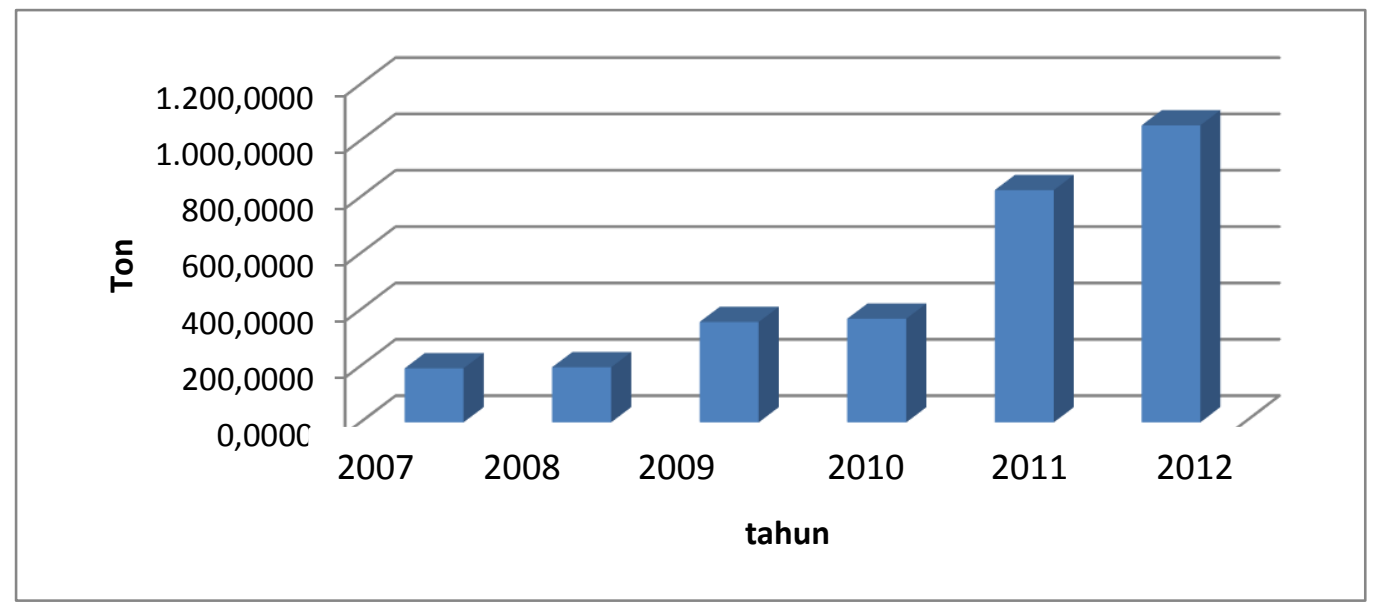

Gambar 3. Perkembangan hasil produksi pada alat tangkap jaring insang hanyut dari tahun 2007-2012 di Perairan Laut Flores ditataran wilayah WPP-RI 713 (Sumber: Dinas Perikanan dan Kelautan Propinsi Sulawesi Selatan).

Hasil tangkapan per unit upaya ikan cakalang pada penggunaan alat tangkap jaring insang hanyut di Perairan Laut Flores dari data sekunder yang diperoleh dari Dinas Perikanan Propinsi Sulawesi Selatan 5 tahun terakhir (2007-2012) dimana CPUE mengalami peningkatan dari tahun 2007 sebesar 0,0076 ton/trip sampai dengan tahun 2009 menjadi 0,02 ton/trip. Kemudian pada tahun 2010 mengalami penurunan yang signifikan yang hanya mencapai 0,0008 ton/trip. Tahun 2011 kembali mengalami sedikit peningkatan yang hanya mencapai 0,0024 ton/trip dan pada tahun 2012 kembali mengalami penurunan sebesar 0,0023 ton/trip. Dari hasil analisis data bahwa potensi lestari atau MSY (Maksimum Sustainable Yield) sebesar 1821,9 ton dimana pada tahun 2012 juga telah melebihi MSYnya namun pada alat tangkap gill net di perairan Laut Flores belum member tekanan terhadap populasi ikan cakalang. Tingkat sedang apabila hasil tangkapan sudah menjadi bagian yang nyata dari potensi lestari baru mencapai $57,8 \%$ dan hal ini penambahan upaya masih memungkinkan untuk mengoptimalkan hasil.

Dari kedua alat tangkap antara alat tangkap pukat cincin (purse seine) dan alat tangkap jaring insang hanyut terlihat bahwa terjadi peningkatan dari tahun 2007 sampai dengan 2012. Akan tetapi alat tangkap pukat cincin lebih cenderung memberi tekanan terhadap populasi ikan cakalang dibandingkan dengan alat tangkap jaring insang hanyut ini dikarenakan bahwa jumlah unit yang melakukan penangkapan ikan cakalang lebih besar atau lebih banyak dibandingkan dengan alat tangkap pukat cincin.. Berdasarkan nilaai CPUE dari tahun 2007 sampai dengan 2012 terlihat semakin meningkat sedangkan nilai MSY ikan cakalang pada alat tangkap jaring insang hanyut sebesar 1821,9 ton nilai produksinya belum melebihi nilai MSYnya. Berdasarkan faktor CPUE dan MSY masih relatif aman terhadap populasi ikan cakalang akan tetapi berdasarkan tingkat keramahan lingkungan dalam penelitian Asruddin et al (2014), bahwa alat tangkap drift gill net di perairan Laut Flores cenderung tidak memenuhi kriteria yang ramah lingkungan.

\section{Kemampuan Tangkap Ikan Cakalang Pada Alat Tangkap Purse Seine Plus Rumpon, Purse Seine Non Rumpon dan Gill Net}

Ketiga alat tangkap purse seine non rumpon, purse seine plus rumpon dan gill net mempunyai lama operasional yang berbedabeda karena adanya spesifikasi bentuk dan ukuran yang berbeda pula. Kemampuan tangkap ditinjau dari efesiensi waktu yang 
digunakan pada pengoperasian alat tangkap sebagai berikut; a) Kemampuan tangkap untuk ikan cakalang pada alat tangkap purse seine plus rumpon 0,39 kg/menit, b) Kemampuan tangkap untuk ikan cakalang pada alat tangkap purse seine non rumpon $0,18 \mathrm{~kg} /$ menit, c) Kemampuan tangkap untuk ikan cakalang pada alat tangkap jaring insang hanyut memiliki kemampuan tangkap yang terendah dibanding alat tangkap pukat cincin semi aktif maupun pukat cincin aktif yaitu hanya sebesar 0,001 $\mathrm{kg} / \mathrm{menit}$.

Bila membandingkan ketiga jenis alat tangkap ikan cakalang di perairan laut flores dengan menggunakan efesiensi waktu maka dapat dikatakan bahwa penangkapan ikan cakalang pada alat tangkap purse seine semi akti cenderung memberikan kontribusi yang tinggi terhadap tekanan populasi ikan cakalang. Secara teknis kemampuan suatu kapal telah memiliki pengaruh terhadap jumlah hasil tangkapan yang diperoleh sebagaimana dalam penelitian Gaffar (2006), bahwa Faktor ukuran kapal, kekuatan mesin, jumlah bahan bakar minyak, panjang jaring, tinggi jaring, jumlah tenaga kerja dan jumlah lampu yang dipergunakan dalam pengoperasian mini purse seine di Kabupaten Jeneponto berpengaruh nyata terhadap produksi pada tingkat kepercayaan $95 \%$. Sedangkan dalam penelitian Asruddin (2015), bahwa faktor teknis seperti besar lingkaran jaring, kecepatan setting dan hauling memiliki hubungan yang berarti dengan hasil tangkapan pada alat pukat cincin semi aktif (purse seine yang menggunakan alat bantu rumpon) di Perairan Kabupaten Selayar.

\section{KESIMPULAN}

Berdasarkan dampak tekanan teknologi penangkapan terhadap ikan cakalang dengan melihat, kemampuan suatu alat tangkap ikan cakalang, Nilai CPUE dan rata-rata ukuran ikan cakalang dapat disimpulkan bahwa: 1) Kemampuan alat tangkap pukat cincin aktif (kategori purse seine aktif) terhadap ikan cakalang rata-rata mampu menangkap 0,39 $\mathrm{kg} /$ Menit, 2) Berdasarkan Nilai CPUE pada produksi ikan cakalang lima tahun terakhir dari tahun 2007-2012 cenderung mengalami peningkatan dan pada tahun 2012 telah melibihi batas MSY (Maksimum Sustainable Yield) yang artinya bahwa alat tangkap pukat cincin semi aktif di perairan Laut Flores telah cenderung memberi tekanan terhadap populasi ikan cakalang.

\section{DAFTAR PUSTAKA}

Asruddin, (2014), Analisis Kegiatan Hulu Perikanan Cakalang (Katsuwonus pelamis) di Perairan Laut Flores. Tesis. Program Pasca Sarjana. Universita Hasanuddin. Makassar.

Asruddin (2015). Hubungan Operasi Penangkapan Ikan Dengan Kapal Purse Seine Ditinjau dari Kecepatan Setting dan Hauling Terhadap Hasil Tangkapan Diperairan Selayar. Jurnal Aquabis, 3 (2). 21-27

Ghaffar, M, A. (2006). Optimalisasi pengembangan Usaha Perikanan Mini Purse Seine Di Kabupaten Jeneponto Provinsi Sulawesi Selatan. Tesis. Sekolah Pasca Sarjana Institut Pertanian Bogor. Bogor

Rukka,A.H. (2006). Teknologi Penangkapan Pilihan Untuk Ikan Cakalang di Perairan Selayar Propinsi Sulawesi Selatan. Sekolah Pascasarjana Institut Pertanian Bogor. Bogor.

Mallawa, A., Amir, F., \& Zainuddin, M. (2016). Keragaan biologi populasi ikan cakalang (Katsuwonus pelamis) yang tertangkap dengan purse seine pada musim timur di perairan laut Flores. Jurnal IPTEKS Pemanfaatan Sumberdaya Perikanan, 1(2).

Mustafa, D. (2007). Studi Keramahan Lingkungan Beberapa Jenis Alat Tangkap Ikan Kembung Lelaki (Rastelliger kanagurata) di Perairan Kabupaten Bulukumba. Jurusan Perikanan. Fakultas Ilmu Kelautan dan Perikanan. Universitas Hasanuddin.

Yahya, A. M., Diniah, Pujiyati, S., Parwinia, E., Sobri, H., Muhammad, S., Rusyadi dan Farhan, A. (2001). Pemanfaatan Sumberdaya Tuna-Cakalang Secara Terpadu. Program Pasca Sarjana IPB. Bogor.

Zainuddin, M. (2009). Estimasi Potensi Dan Pemetaan Daerah Potensial Penangkapan Ikan Pelagis Di Perairan Selayar Dengan Menggunakan Citra Satelit Aqua/Modis. Torani (Jurnal Ilmu Kelautan dan Perikanan) Vol, 19. 
Zainuddin, M., Nelwan, A., Farhum, S. A., Hajar, M. A. I., \& Kurnia, M. (2013). Characterizing Potential Fishing Zone of Skipjack Tuna during the Southeast Monsoon in the Bone Bay-Flores Sea Using Remotely Sensed Oceanographic Data. International Journal Of Geosciences, 4(01), 259. 